\title{
Information and Husband's Support on Implementation Postpartum Gymnastics during COVID 19 Pandemic in Indonesia
}

\author{
Yunik Windarti $^{1 *}(\mathbb{D})$, Yasi Anggasari ${ }^{1}$, Siti Nur Hasina $^{2}$ (D) Firdaus Firdaus $^{2}$ (ID \\ ${ }^{1}$ Department of Midwifery, Faculty of Nursing and Midwifery, Nahdlatul Ulama University Surabaya, Surabaya, East Java, \\ Indonesia; ${ }^{2}$ Department of Nursing, Faculty of Nursing and Midwifery, Nahdlatul Ulama University Surabaya, Surabaya, \\ East Java, Indonesia
}

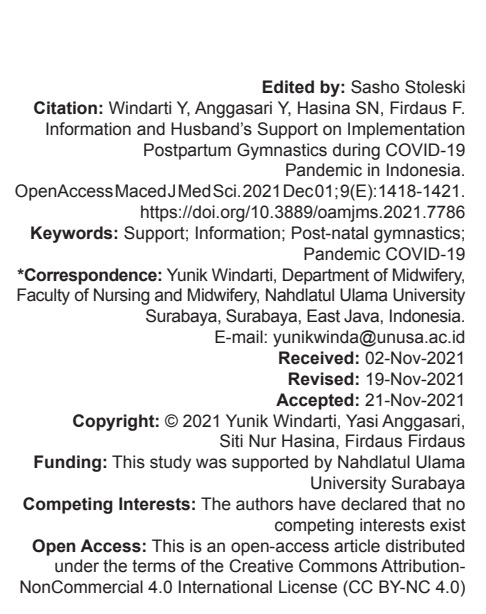

Abstract

BACKGROUND: The practice of post-natal gymnastics in Indonesia is still little done by post-partum mothers both before and during the COVID pandemic 19. Some of the contributing factors include lack of knowledge about postnatal gymnastics, fatigue, and the mother's mindset about the importance of post-natal gymnastics for health which is still lacking. Post-delivery exercise can help mothers to get back to their normal health as they were before pregnancy.

AIM: This study aims to analyze the effect of information and husband's support on the implementation post-natal gymnastics during the COVID-19 pandemic.

METHODS: Non-experimental research design: cross-sectional analytic, the independent variable is husband's information and support and the dependent variable is postpartum exercise. This research was conducted in April - August 2021. The population of postpartum mothers was 102, the sampling technique was incidental sampling in Wonokromo Village, Surabaya, East Java, Indonesia. Research instrument with a questionnaire. The data were analyzed using the Multiple Logistics Regression test.

RESULTS: The results showed that partial there was a significant effect of husband's support $(p=0.013)$ on postnatal exercise, but for information during the pandemic there was no effect $(p=0.998)$ on postpartum exercise The results of the analysis showed that the OR value of the information was $1.615 \mathrm{E} 9(95 \% \mathrm{Cl}: 0.000-0.000)$ and the OR of husband's support was 3.385 (95\% Cl: 1.289-8.886).

CONCLUSION: Husband's support during the COVID-19 pandemic affects mothers in doing postnatal exercise. Obtaining information about postnatal exercise during the COVID-19 pandemic does not affect the mother in its implementation.

\section{Introduction}

The COVID-19 pandemic in Indonesia has been almost 3 years, but until now it is still not over. Data shows that as of December 31, 2020, the Recovery Rate in Indonesia was $82.2 \%$ with a total of 611,097 cases recovered and the Case Fatality Rate (CFR) of $3.0 \%$ with a total of 22,138 deaths [1]. The province with the largest CFR is East Java, which is 6.9\% [2]. Various efforts have been made by the Indonesian government to suppress the spread of COVID-19, namely Large- Scale Social Restrictions (PSBB) in accordance with Minister of Health Regulation Number 9 of 2020 concerning Guidelines for Social Restrictions Large-Scale in the context of Accelerating the Handling of COVID-19 [3]. In addition, they must also apply the $3 \mathrm{M}$ health protocol (wear masks, wash hands, and maintain distance) and stay away from crowds [4]. This pandemic affects various aspects of life, especially health which must adapt to existing conditions. The same goes for post-partum mothers. Conditions during pregnancy, childbirth, and now the postpartum period really need support from various parties, especially during a pandemic.

Puerperium is the period after childbirth in which the female reproductive system recovers to a pregnant state which lasts for 6 weeks [5]. During this time, the right information will help the mother get healthy again, one of which is information about the needs of postpartum mothers, namely exercise. Providing good information will influence mothers to want to do early postpartum gymnastics [6]. There are many benefits of this exercise for mothers, including improving blood circulation, restoring stretching of the back, abdominal and pelvic floor muscles, and recovering quickly, accelerating uterine involution, restoring uterine function, removing normal types of lochia, and preventing postpartum complications [7], [8], [9], [10].

Postpartum care by involving the family is a form of support for the mother to return to health soon. Husband's support influences the mother to prevent depression [11]. Husbands who provide support to their wives to do postpartum gymnastics will affect the mother's physical and psychological health. 


\section{Methods}

Non-experimental research design: crosssectional analytic, the independent variable is information and husband's support and the dependent variable is postpartum exercise. This research was conducted for 5 months, from April to August 2021. The participants of this study were postnatal mothers after 10 days, with incidental sampling technique totaling 102 respondents in Wonokromo Village, Surabaya City, East Java Province, Indonesia. In this study, each participant consented by filling out an informed consent form. Participants in this study have the right to withdraw or refuse to participate. The procedure of this research is to fill in the research instrument in the form of a questionnaire after agreeing to the informed consent. Data were collected and analyzed using the Multiple Logistics Regression test $p<0.05$

\section{Results}

Table 1 shows that the level of education almost half of the respondents $(44.1 \%)$ had higher education, most $(53.9 \%)$ did not work, and most (52.9\%) were multiparous.

Table 1: Characteristic respondents by education, employment, and parity

\begin{tabular}{lll}
\hline Category & $\mathrm{n}$ & $\%$ \\
\hline Education & 16 & 15.7 \\
$\quad$ Basic & 41 & 40.2 \\
$\quad$ Secondary & 45 & 44.1 \\
$\quad$ Higher & & \\
Employment & 55 & 53.9 \\
$\quad$ Not working & 47 & 46.1 \\
$\quad$ Working & & \\
Parity & 48 & 47.1 \\
$\quad$ Primiparas & 54 & 52.9 \\
$\quad$ Multipara & &
\end{tabular}

Table 2 showed that almost all (83.3\%) mothers received information about post-partum exercise, had husband's support $55.8 \%$, and did $56.9 \%$ post-partum exercise.

Table 2: Characteristics of respondents based on information, husband's support, and post-partum exercise $(n=b b 102)$

\begin{tabular}{lll}
\hline Category & $\mathrm{n}$ & $\%$ \\
\hline Information & & \\
$\quad$ Yes & 85 & 83.3 \\
$\quad$ No & 17 & 16.7 \\
Husband's support & & \\
$\quad$ Yes & 57 & 55.8 \\
$\quad$ No & 45 & 44.2 \\
Post-partum exercise & & \\
$\quad$ Yes & 58 & 56.9 \\
$\quad$ No & 44 & 43.1 \\
\hline Primary Data, 2021. & &
\end{tabular}

Table 3 shows that respondents who did not receive information about post-partum exercise, all $(100 \%)$ did not do postpartum exercise. Respondents who received information about post-partum exercise, most $(68.24 \%)$ did post-partum exercise.
Table 3: Cross-tabulation of information and postpartum exercise $(n=102)$

\begin{tabular}{|c|c|c|c|}
\hline \multirow[t]{3}{*}{ Information on } & \multicolumn{2}{|c|}{ Post-partum gymnastics } & \multirow{3}{*}{$\begin{array}{l}\text { Total } \\
\mathrm{n}(\%)\end{array}$} \\
\hline & No & Yes & \\
\hline & $\mathrm{n}(\%)$ & $\mathrm{n}(\%)$ & \\
\hline No & $17(100)$ & $0(0)$ & $17(100)$ \\
\hline Yes & $27(31.76)$ & $58(68.24)$ & $85(100)$ \\
\hline
\end{tabular}

Table 4 shows that the majority of respondents who did not receive support from their husbands $(68.89 \%)$ did not do post-partum exercise. Respondents who received support from their husbands, most (77.19\%) did post-partum exercise.

Table 4: Cross-tabulation of husband support and post-partum exercise $(n=102)$ exercise

\begin{tabular}{lllll}
\hline Husband's support & \multicolumn{2}{l}{ Post-partum } & & Total \\
\cline { 2 - 3 } & No & & Yes \\
\cline { 2 - 3 } & $\mathrm{n}(\%)$ & & \\
\hline No & $31(68.89)$ & & $14(31.11)$ & \\
Yes & $13(22.81)$ & $44(77.19)$ & $57(100)$ \\
\hline Primary Data, 2021. & & & $57(100)$ \\
\hline
\end{tabular}

The test results showed that partial there was a significant effect of husband's support $(p=0.013)$ on post-partum exercise, but for information during the COVID-19 pandemic, there was no effect $(p=0.998)$ on post-partum exercise. The results of the analysis (Table 5) showed that the OR value of the information was 1.615E9 (95\% Cl: $0.000-0.000)$ and the OR of husband's support was 3.385 (95\% Cl: 1.289-8.886).

\section{Discussion}

The post-partum phase is divided into three, namely the acute period, is the subacute postpartum period, and the delayed post-partum period [12]. Post-partum exercise is carried out in the subacute period. Post-partum exercise is one of the needs of mothers after giving birth. Movements that are carried out gradually and regularly are very helpful for mothers to immediately return to health as before. Physical activity and exercise are well-established factors promoting lifelong physical health and enhancing wellness in the general population [13]. Physical activity during postpartum is both a recommended and an essential contributor to maternal health [14].

In this study, participants who received information about post-partum exercise $68.24 \%$ did post-partum exercise. Good information to the mother will influence the mother in doing something. After the analysis, it turns out that providing information about this exercise has no effect on the implementation of postpartum gymnastics with a value of $p=0.998>p=0.05$. There are other factors that are more influential than the provision of this information. Before and during the COVID-19 pandemic, it had no effect on mothers. The implementation of gymnastics that can be done at home makes mothers do them 
Table 5: Test multiple logistic regression analysis

\begin{tabular}{llllll}
\hline Variable & Wald & OR & \multicolumn{2}{c}{$95 \%$ Confidence Interval } & p-value \\
\cline { 3 - 5 } & & & Lower limit & Upper limit & \\
\hline Constant & 0000 & 0000 & & 0900 & 0998 \\
Information & 0000 & $1.615 \mathrm{E} 9$ & 0000 & 0000 & 0998 \\
husband Support & 6130 & 3385 & 1289 & 8886 & 0013 \\
N observations & 102 & & & & \\
-2 log likelihood & 139474 & & & & \\
Negelkerke R Square & 0430 & & & & \\
\hline
\end{tabular}

according to their wishes. Based on the results of the questionnaire, some mothers thought that postpartum gymnastics was not too important considering the experience of giving birth before also not doing this post-partum exercise. It is known that $52.9 \%$ of respondents are multiparous, where the mother already has more than 1 child. A person's experience becomes one of the determinants of decision making whether it is positive or negative. In general, multiparas have had experience and tend to do better than their previous experience [15]. The role of health workers is very important to change the mother's mindset about post-partum exercise. Success in giving understanding to mothers will affect their health status. Midwives or any healthcare provider attending to a woman at birth is expected to provide good postnatal information [16].

Most of the study participants $(53.9 \%)$ did not work or were housewives. Although information can be obtained through various media, in fact, $16.7 \%$ of participants have not received information about this post-partum exercise. Most of the information about postpartum exercise comes from health workers. Post-partum exercise is carried out from day 1 to day 10 post-partum, carried out gradually, systematically, continuously [17], [18]. During the COVID-19 pandemic, the implementation of post-partum exercises is carried out only at home.

With almost half of the education level (44.1\%) having higher education, it will be very supportive for mothers to access information about this post-partum exercise. The level of education makes it easier for someone to more quickly understand the information that is obtained. The higher the level of education, the better the ability to absorb information [19].

The postpartum period involves a major life transition that requires increased levels of social, emotional, and health professional support [20]. Social support would improve a health-promoting lifestyle post-partum women [21]. In the family, husband's support has a very important role for postpartum mothers. This study revealed that participants who received support from their husbands $77.19 \%$ did postpartum exercise. The results showed that there was a significant effect of husband's support on postpartum mothers during the COVID-19 pandemic with a value of $p=0.013<p=0.05$. Most of the husbands of the participants did not work or work from home during this COVID-19 pandemic, so they could give good attention to postpartum mothers.
Husband's support for postpartum mothers is in the form of support for sentences asking for exercise, getting drinks, helping to prepare places and rooms, helping to take care of babies during exercise, accompanying mothers during exercise. By his constant presence near the mother and his care of she'is, a father will assure safety and be able to prevent complications [22]. This husband's support can reduce postpartum depression that sometimes occurs in mothers. a supportive partner reduces the risk of postpartum depression both directly and by reducing the effects of stress [23].

The most common form of husband support is providing support in the form of invitations to exercise, reaching 57 people $(55.9 \%)$. Some mothers mentioned that the obstacles they often experienced were forgetting the stages of movement, there was no time for exercise so it was not routine, and they were afraid of pain in post-partum wounds that had not healed. Social support to have a positive impact across a range of physical behaviors and mental health [24]. With full support, the obstacles faced by post-partum mothers are meaningless. When mothers carry out post-partum exercises properly and regularly, they can improve their health status and at the same time help the government in reducing maternal mortality in Indonesia and indirectly help fight the COVID-19 virus in Indonesia. The Indonesian government has issued policies related to the corona virus, namely the policy of staying at home, social restrictions, physical restrictions, use of personal protective equipment, maintaining personal hygiene, working and studying at home, post-poning all activities that gather large crowds, large-scale social restrictions, to the policy of implementing the new normal policy [25].

\section{Conclusion}

Husband's support during the COVID-19 pandemic affects mothers in doing gymnastics after giving birth. Obtaining information about post-natal gymnastics during the COVID-19 pandemic has no effect. Husband's support dominates the reason for implementing post-partum gymnastics practices during the COVID-19 pandemic.

\section{Acknowledgment}

The research team would like to thank all the participants of this study and Nahdlatul Ulama University Surabaya for supporting this research. 


\section{References}

1. Ministry of Health RI. Indonesia Health Profile for 2020; 2020. Available from: https://www.pusdatin.kemkes.go.id/resources/download/ pusdatin/profil-kesehatan-indonesia/Profil-KesehatanIndonesia-Tahun-2020.pdf. [Last accessed on 2021 Oct 20]. https://doi.org/10.25077/jikesi.v1i2.95

2. D. P2P. Disease Prevention and Control. Ministry of Health RI; 2021. Available from: http://www.p2p.kemkes.go.id. [Last accessed on 2021 Oct 22].

3. Permenkes No. 9 of 2020 Concerning PSBB Guidelines in the Context of Accelerating the Handling of COVID-19. 2020. Available from: https://peraturan.bpk.go.id/Home/ Details/135220/permenkes-no-9-tahun-2020 [Last accessed on 2021 Oct 22].

4. Indonesian Recovery Rate and Case Fatality Rate Analysis COVID-19 Indonesia Recovery Rate and Case Fatality Rate Analysis Indonesia COVID-19 Recovery Rate and Case Fatality Rate Analysis. 2021. Available from: https://www.worldometers. info/coronavirus/country/indonesia/. [Last accessed on 2021 Oct 22].

5. Ambarwati W. Postpartum Midwifery Care. United States: ACOG; 2010

6. Windarti Y, Dewi M. Influence of information sources and parity on mother's desire to do early partnership exercises. Reprod Health. 2019;7(2):32-8.

7. Rahayu S, Solekah U. Influence of public exercise on uternal involution in post partum mothers at Mariana Puskesmas, Banyuasin district. J Midwifery 2020;12(2):157. https://doi. org/10.35872/jurkeb.v12i02.388

8. Rullynil NT, Ermawati E, Evareny L. The Effect of Postpartum Gymnastics on Reduction of Uterine Fundal Height in Post Partum Mothers at RSUP DR. M. Djamil Padang. J Health Andalas 2014;3(3):111. https://doi.org/10.25077/jka.v3i3.111

9. Ineke I. The effect of postpartum gymnastics on uterine fundal height and Lochea types in Primiparas. J IIm Midwife. 2016;1(3):45-54.

10. Colin V, Keraman B, Sundari AD. Effect of postpartum gymnastics on decreasing height of uterine fundus in post partum mothers in BPM midwife Susi Irma Navia, S.ST Bengkulu City. J Health Sci. 2019;26(1):70-8. https://doi. org/10.37638/jsk.26.1.70-78

11. Lee JY, Hwang JY. A study on postpartum symptoms and their related factors in Korea. Taiwan J Obstetr Gynecol 2015;54(4):355-63.

12. Romano M, Cacciatore A, Giordano A, La Rosa B. Postpartum period: Three distinct but continuous phases. J Prenat Med. 2010;4(2):22-5 PMid:22439056

13. Zourladani A, Zafrakas M, Chatzigiannis B, Papasozomenou P, Vavilis D, Matziari C. The effect of physical exercise on postpartum fitness, hormone and lipid levels: A randomized controlled trial in primiparous, lactating women. Arch Gynecol Obstetrics. 2015;291(3):525-30. https://doi.org/10.1007/ s00404-014-3418-y

PMid:25138123

14. Adeniyi AF, Ogwumike OO, Bamikefa TR. Postpartum exercise among nigerian women: Issues relating to exercise performance and self-efficacy. ISRN Obstet Gynecol. 2013;2013:294518. https://doi.org/10.1155/2013/294518

PMid:23844290

15. Windarti Y, Dewi UM. Influence of parity and public counseling media on the ability of post partum mother's self-care at BPM Vivi Surabaya. J Health Sci. 2018;11(1):547. https://doi. org/10.33086/jhs.v11i1.547

16. Rotich E, Wolvaardt L. A descriptive study of the health information needs of Kenyan women in the first 6 weeks postpartum. BMC Pregnancy Childbirth. 2017;17(1):385. https:// doi.org/10.1186/s12884-017-1576-1

17. Maryunani S. Pregnancy Exercise, Postpartum Gymnastics and Music Therapy. Jakarta: CV Trans Info Media; 2011.

18. Asih Y. Textbook of Postpartum and Breastfeeding Midwifery Care. Jakarta: Trans Info Media; 2016.

19. Yugistyawati A. The effect of postpartum health education on the ability of post-section caesarea (SC) self-care for mothers. J Ners Indones Midwifery 2016;1(3):96. https://doi. org/10.21927/jnki.2013.1(3).96-100

20. Chivers BR, Garad RM, Moran LJ, Lim LJ, Harrison CL. Support seeking in the postpartum period: Content analysis of posts in web-based parenting discussion groups. J Med Internet Res. 2021;23(7):e26600. https://doi.org/10.2196/26600

21. Hajimiri K, Shakibazadeh E, Haeri Mehrizi AA, Shabbidar S, Sadeghi R. The impact of general health and social support on health promoting lifestyle in the first year postpartum: the structural equation modeling. Electron Physicians. 2018;10(1):6231-9. https://doi.org/10.19082/6231 PMid:29588825

22. Firouzan V, Noroozi $M$, Mirghafourvand $M$, Farajzadegan $Z$. Participation of father in perinatal care: a qualitative study from the perspective of mothers, fathers, caregivers, managers and policymakers in Iran. BMC Pregnancy Childbirth. 2018;18(1):297. https://doi.org/10.1186/s12884-018-1928-5 PMid:29996793

23. Bintaş Zörer P, Tulum Akbulut $S$, Dirik G. Doğum sonras depresyonda bağlanma rüntüleri ve partner desteğinin rolü. Psikiyatr Guncel Yaklasimlar Curr Approaches Psychiatry. 2019;11(2):154-66. https://doi.org/10.18863/pgy.387288

24. Faleschini S, Millar L, Rifas-Shiman SL, Skouteris H, Hivert MF, Oken E. Women's perceived social support: Associations with postpartum weight retention, health behaviors and depressive symptoms. BMC Womens Health. 2019;19(1):143. https://doi. org/10.1186/s12905-019-0839-6

25. Tuwu D. Government policy in managing the COVID-19 pandemic. J Publicuho. 2020;3(2):267. 